\title{
Pengaruh Pendidikan Kewirausahaan, Motivasi Berwirausaha, Lingkungan Keluarga dan Ekspektasi Pendapatan terhadap Minat Berwirausaha Mahasiswa Akuntansi (Studi Kasus pada Mahasiswa Aktif dan Alumni Prodi Akuntansi Fakultas Ekonomi Universitas Sarjanawiyata Tamansiswa)
}

\section{The Effect of Entrepreneurial Education, Enterprise Motivation, Family Environment and Income Expectation on Accounting Students \\ (Case Study on Active Students and Alumni of Accounting Program Faculty of Economics, Sarjanawiyata University Tamansiswa)}

\author{
Syafiya Fathiyannida ${ }^{1}$, Teguh Erawati ${ }^{2}$ \\ 1 Universitas Sarjanawiyata Tamansiswa - Yogyakarta \\ 2Universitas Sarjanawiyata Tamansiswa - Yogyakarta \\ Email : Syafiya.ust@gmail.com
}

\begin{abstract}
ABSTRAK
Metode penelitian ini menggunakan metode deskriptif kuantitatif dan data primer kuesioner. Penelitian ini mengambil sampel mahasiswa angkatan 2016-2018 Prodi Akuntansi Fakultas Ekonomi Universitas Sarjanawiyata Tamansiswa Yogyakarta (FE UST). Pengolahan data diuji dengan uji asumsi klasik dan uji hipotesis dengan Uji Normalitas, Uji Linearitas, Uji Multikoleniaritas, Uji Heteroskedastitas, Uji T, Uji F, Regresi Linear Berganda dan R2. Teknik pengambilan sampel menggunakan snowball sampling. Pengumpulan dilakukan dengan cara membagikan link kuesioner dalam bentuk google form. Jumlah kuesioner yang diolah sebanyak 85 kuesioner. Hasil penelitian ini menunjukkan bahwa pendidikan kewirausahaan berpengaruh negatif terhadap minat berwirausaha mahasiswa akuntansi, sedangkan motivasi berwirausaha, lingkungan keluarga, dan ekspektasi pendapatan berpengaruh positif terhadap minat berwirausaha mahasiswa akuntansi.

Kata Kunci: Pendidikan kewirausahaan, motivasi berwirausaha, lingkungan keluarga, ekspektasi pendapatan, minat berwirausaha
\end{abstract}

\begin{abstract}
This research method uses quantitative descriptive methods and primary questionnaire data. This study took a sample of students of the 2016-2018 class of Accounting Study Program, Faculty of Economics, Sarjanawiyata Tamansiswa University, Yogyakarta (FE UST). Data processing was tested by classical assumption test and hypothesis test with normality test, linearity test, multicollinearity test, heteroscedasticity test, $T$ test, $F$ test, multiple linear regression and $R 2$. The sampling technique used snowball sampling. The collection is done by distributing the questionnaire link in the form of a google form. The number of questionnaires that were processed was 85 questionnaires. The results of this study indicate that entrepreneurship education has a negative effect on the entrepreneurial interest of accounting students, while entrepreneurial motivation, family environment, and income expectations have a positive effect on the interest in entrepreneurship in accounting students. .

Keywords: Entrepreneurship education, entrepreneurial motivation, family environment, income expectations, interest in entrepreneurship
\end{abstract}




\section{PENDAHULUAN}

Pengangguran, bukanlah penyebab seseorang untuk tidak mau bekerja, melainkan akibat sulitnya mendapatkan pekerjaan (Setiawan, 2016), selain itu persaingan antara antara yang sudah berpengalaman maupun fresh graduate semakin ketat. Penyebab terjadinya pengangguran dan kemiskinan adalah jumlah lapangan pekerjaan di seluruh sektor tidak sebanding dengan jumlah lulusan atau penawaran tenaga kerja baru yang dihasilkan di berbagai level pendidikan (Saiman, 2009).

Data yang bersumber dari Badan Pusat Statistik (BPS) menunjukkan perbandingan Agustus 2014 - Agustus 2018, tingkat pengangguran lulusan SMK turun dari 9,15\% menjadi 7,95\%. Lulusan diploma (D1-D3) turun dari 6,14\% menjadi 6,02\%, sedangkan lulusan SMK, tetap, yakni $11,24 \%$. Kenaikan tingkat pengangguran justru terjadi pada lulusan sarjana yakni dari $5,65 \%$ menjadi $5,89 \%$. Artinya lulusan sarjana dari pendidikan yang lebih tinggi semakin meningkat ditahun 2019 (Purnomo, 2020). Hal ini dapat disebabkan oleh sedikitnya kualitas lulusan sarjana dan kurangnya pengalaman kerja. Menumbuhkan jiwa berwirausaha pada mahasiswa dapat mengurangi tingkat pengangguran di Indonesia. Sebab seorang wirausaha memiliki potensi untuk berprestasi dan memiliki motivasi yang besar untuk maju. Selain itu, seorang wirausaha mampu mengatasi kemiskinan tanpa menunggu bantuan dari pihak lain. Kualitas manusia wirausaha ditentukan oleh kemauan untuk belajar, serta kemampuan dan keterampilannya (Hantoro, 2005).

Menurut Inayati (2018), pendidikan kewirausahaan mempengaruhi minat mahasiswa dalam berwirausaha. Satu-satunya cara atau perjuangan untuk mewujudkan manusia yang mempunyai sikap, moral, dan keterampilan wirausaha adalah dengan pendidikan. Pendidikan membuat wawasan individu menjadi lebih percaya diri, mengambil keputusan yang tepat, bisa memilih, meningkatkan kreativitas dan inovasi serta membina moral, karakter dan intelektual. Menurut Noviantoro (2017), untuk dapat menambah jumlah wirausahaan muda di Indonesia dibutuhkan motivasi berwirausaha yang kuat dari mahasiswa. Motivasi yang kuat mendorong keberhasilan pada kebanyakan orang. Salah satu pendorong untuk meningkatkan minat mahasiswa dalam berwirausaha adalah motivasi berwirausaha. Motivasi yang besar di dalam diri mahasiswa dapat menentukan tingkat keberhasilan dalam berwirausaha. Semakin besar usaha untuk mewujudkan tujuannya, semakin besar pula motivasi yang dimiliki seseorang.

Orang tua harus mampu mengajarkan attitude yang baik kepada anak-anaknya, sehingga di luar lingkungan keluarga anak tersebut dapat menjaga nama baik keluarga. Lingkungan keluarga merupakan tempat aktivitas utama kehidupan seseorang berlangsung, sehingga keluarga menjadi penentu dalam perkembangan seseorang. Dalam keluarga, orang tua akan mengarahkan anaknya untuk kehidupan dimasa depannya. Secara tidak langsung, orang tua dapat mempengaruhi anaknya dalam memilih pekerjaan. Dengan demikian, dukungan lingkungan keluarga dapat mendorong anaknya untuk menjadi wirausaha (Setiawan, 2016).

Ekspektasi atau harapan atas penghasilan yang lebih baik merupakan salah satu faktor yang mempengaruhi keinginan seseorang untuk berwirausaha. Ekspektasi atau harapan atas penghasilan yang lebih baik merupakan salah satu faktor penentu keinginan seseorang untuk berwirausaha. Jika seseorang berharap untuk mendapatkan penghasilan yang lebih tinggi dengan berwirausaha, maka seseorang tersebut akan semakin terdorong untuk menjadi wirausaha. Seseorang yang berwirausaha akan mendapatkan penghasilan dari posisinya sebagai seorang manager atau pemilik usaha (Utami, 2017). 


\section{LANDASAN TEORI}

\section{Theory of Planned Behavior (TPB)}

Theory of Planned Behavior (TPB) sering digunakan untuk penelitian perilaku. TPB biasanya menjelaskan niat seseorang yang kemudian menjelaskan perilaku tersebut. Menurut Ajzen (1991) Theory of Planned Behavior merupakan teori yang menjelaskan permasalahan apa yang membuat seseorang melakukan tindakan tertentu, oleh karena itu teori ini mampu menjelaskan perilaku seseorang dalam bidang kewirausahaan yang didukung oleh penjelasan Ajzen (1991), bahwa Theory of Planned Behavior is suitable to explain any behaviour which requires planning such as entrepreneurship yang artinya sebagai teori perilaku yang direncanakan itu cocok untuk menjelaskan perilaku yang memerlukan perencanaan, seperti kewirausahaan.

\section{Teori Atribusi}

Teori atribusi menjelaskan mengenai perilaku orang lain atau dirinya sendiri melalui dua faktor, yaitu faktor internal dan faktor eksternal. Faktor internal dapat berkaitan dengan sifat, karakter, sikap dan lain sebagainya, sedangkan faktor eksternal biasa dikaitkan dengan situasi atau kondisi lingkungan tertentu yang dapat mempengaruhi perilaku individu menurut Heider (1958) sebagai pencetus teori atribusi yang menggambarkan bahwa kekuatan internal dan eksternal secara bersama-sama dapat menentukan perilaku seseorang.

\section{Minat Berwirausaha}

Menurut Paramitasari (2016), minat berwirausaha merupakan kecenderungan hati dari dalam diri seseorang pada proses merencanakan, mengorganisir, mengatur, menanggung risiko dan mengembangkan usaha yang diciptakannya untuk mencapai tujuan dengan keinginan dan keberanian untuk menciptakan bidang usaha melalui ide-ide kreatif, inovatif, serta dapat mengelola peluang yang ada dengan cara bekerja keras, semangat yang tinggi karena minat berwirausaha harus melihat ke depan dalam mendirikan usaha.

\section{Pendidikan Kewirausahaan}

Menurut Sutrisno (2003), pendidikan berwawasan kewirausahaan adalah pendidikan yang menerapkan prinsip-prinsip dan metodologi ke arah pembentukan kecakapan hidup melalui kurikulum yang terintegrasi yang dikembangkan di sekolah kepada peserta didiknya. Pendidikan yang demikian merupakan Pendidikan yang berorientasi pada pembentukan jiwa entrepreneurship, yaitu yang mempunyai keberanian dan kemauan menghadapi problema hidup dan kehidupan secara wajar, jiwa kreatif untuk menyelesaikan problema tersebut, jiwa mandiri dan tidak bergantung pada orang lain.

\section{Motivasi Berwirausaha}

Motivasi berwirausaha dapat dilatih, dipelajari dan dikembangkan oleh seseorang, karena motivasi berwirausaha tidak dibawa sejak lahir. Dorongan yang timbul dari seseorang untuk mengambil dan melakukan kegiatan yan berkaitan dengan kewirausahaan dapat disebut juga dengan motivasi berwirausaha (Noviantoro, 2017).

\section{Lingkungan Keluarga}

Menurut Semiawan (2010), lingkungan keluarga merupakan media pertama dan utama yang dapat mempengaruhi perkembangan anak. Lingkungan keluarga adalah kelompok terkecil di masyarakat dan juga merupakan lingkungan pertama yang mempengaruhi perilaku anak. Dalam lingkungan keluarga seorang anak mendapatkan perhatian, kasih sayang, dorongan dan bimbingan dari orang tua bisa juga dari saudara kandungnya yang dapat membantu mengetahui potensi dan anak untuk perkembangan dimasa mendatang (Sintya, 2019).

\section{Ekspektasi Pendapatan}

Ekspektasi pendapatan adalah keinginan atau harapan seseorang untuk mendapatkan penghasilan yang besar dan tidak terbatas. Jika seseorang berharap memperoleh pendapatan 
yang besar dalam berwirausaha, maka seseorang tersebut akan terdorong menjadi seorang wirausahawan (Utami, 2017).

\section{Pengembangan Hipotesis}

\section{Pengaruh Pendidikan Kewirausahaan Terhadap Minat Berwirausaha Mahasiswa Akuntansi FE UST}

Melalui Pendidikan kewirausahaan seseorang dapat mengaplikasikan teori yang diperolehnya pada ide atau inovasi di bidang kewirausahaan dan diharapkan dapat menciptakan peluang untuk berwirausaha. Salah satu mata kuliah di Program Studi Akuntansi FE UST yaitu kewirausahaan. Mahasiswa diminta untuk membuat kelompok dan menjual produk hasil berdasarkan kreatifitas dan inovasi baik produk jasa, makanan dan kerajinan, sehingga dapat menumbuhkan minat untuk berwirausaha.

Pendidikan Kewirausahaan dapat dikaitkan dengan Theory of Planned Behavior (TPB) yang sesuai dengan konsep yang mengacu pada tekanan sosial yang muncul yaitu norma subjektif untuk melakukan atau tidak melakukan perilaku tersebut. Seorang mahasiswa yang memiliki minat berwirausaha cenderung memperhatikan dengan seksama saat mengikuti perkuliahan kewirausahaan. Oleh karena itu, pendidikan kewirausahaan dapat dikaitkan dengan Theory of Planned Behavior (TPB).

Pendidikan Kewirausahaan yang diterima mahasiswa dalam perkuliahan dapat dikaitkan juga dengan teori atribusi. Teori atribusi memiliki faktor internal dan faktor eksternal yang dapat memunculkan minat berwirausaha mahasiswa, hal ini karena pendidikan kewirausahaan merupakan faktor eksternal yang berasal dari luar kondisi lingkungan sekitar. Mahasiswa yang memiliki pengetahuan kewirausahaan akan lebih tertarik untuk berwirausaha, sebaliknya, mahasiswa yang tidak mempunyai pengetahuan kewirausahaan cenderung tidak memiliki minat untuk berwirausaha. Oleh sebab itu, pendidikan kewirausahaan dapat dikaitkan dengan teori atribusi. Berdasarkan penjelasan dan analisis pengembangan hipotesis diatas, maka hipotesis dalam penelitian ini adalah:

H1: Pendidikan Kewirausahaan Berpengaruh Positif Terhadap Minat Berwirausaha Mahasiswa Akuntansi FE UST

\section{Pengaruh Motivasi Berwirausaha Terhadap Minat Berwirausaha Mahasiswa Akuntansi FE UST}

Menurut Noviantoro (2017) motivasi berwirausaha merupakan dorongan psikologis seseorang untuk melakukan wirausaha baik dari dalam maupun luar diri. Kondisi psikologis tersebut dapat memberikan dampak yang cukup besar terhadap keberhasilan dari suatu kegiatan yang berasal dari dalam tubuh manusia. Dengan adanya dorongan tersebut, seseorang dapat menentukan nasibnya di masa depan dengan menentukan usaha apa yang akan dikelolanya.

Motivasi berwirausaha dapat dikaitkan dengan Theory of Planned Behavior (TPB). Sesuai konsep norma subjektif yang mengacu pada sebuah tekanan sosial untuk melakukan atau tidak melakukan perilaku tersebut baik dari internal maupun eksternal pribadi seseorang, seperti motivasi. Oleh karena itu, semakin besar motivasi berwirausaha dari internal maupun eksternal pribadi seseorang semakin tinggi pula seseorang untuk berminat menjadi wirausahawan. Jadi, motivasi berwirausaha dapat dikaitkan dengan Theory of Planned Behavior (TPB). 
Teori atribusi menjelaskan mengenai perilaku orang lain atau dirinya sendiri melalui dua faktor, yaitu faktor internal dan faktor eksternal. Motivasi berwirausaha mencakup dua faktor sekaligus, faktor internal seperti keinginan yang kuat dan faktor eksternal seperti lingkungan sekitar yang dapat menumbuhkan motivasi untuk berwirausaha. Oleh karena itu, motivasi berwirausaha dapat dikaitkan dengan teori atribusi. Berdasarkan penjelasan dan analisis pengembangan hipotesis diatas, maka hipotesis dalam penelitian ini adalah:

H2: Motivasi Berwirausaha Berpengaruh Positif Terhadap Minat Berwirausaha Mahasiswa Akuntansi FE UST

\section{Pengaruh Lingkungan Keluarga Terhadap Minat Berwirausaha Mahasiswa Akuntansi FE UST}

Menurut Sintya (2019), lingkungan keluarga merupakan lingkungan yang pertama dalam kehidupan seseorang. Lingkungan keluarga terdiri dari ayah, ibu, saudara serta keluarga terdekat lainnya. Orang tua dapat mempengaruhi masa depan anaknya dengan memberikan dukungan dan motivasi dalam memilih karir anaknya, menjadi seorang wirausahawan tidak lepas dari dukungan keluarga terutama orang tua, apabila keluarga memberikan pengaruh positif terhadap minat berwirausaha maka seseorang akan memiliki minat untuk berwirausaha.

Lingkungan keluarga dapat dikaitkan dengan Theory of Planned Behavior (TPB). Semakin kuat dukungan dari keluarga, seseorang cenderung untuk menumbuhkan minat berwirausaha. Hal ini sesuai dengan norma subjektif pada sebuah tekanan sosial yang muncul untuk melakukan atau tidak melakukan perilaku tersebut. Oleh karena itu lingkungan keluarga dapat dikaitkan dengan Theory of Planned Behavior (TPB).

Lingkungan keluarga merupakan faktor eksternal yang dapat mempengaruhi mahasiswa dalam memunculkan minat berwirausaha. Lingkungan keluarga yang mendukung anaknya dapat menumbuhkan minat untuk berwirausaha, selain itu orang tua yang menjadi seorang wirausaha juga dapat menjadi panutan anaknya untuk menjadi seorang wirausaha. Sebaliknya, apabila tidak ada dukungan dari keluarga, untuk menumbuhkan minat pada diri mahasiswa akan menjadi sulit. Oleh karena itu, lingkungan keluargadapat dikaitkan dengan teori atribusi. Berdasarkan penjelasan dan analisis pengembangan hipotesis diatas, maka hipotesis dalam penelitian ini adalah:

H3: Lingkungan Keluarga Berpengaruh Positif Terhadap Minat Berwirausaha Mahasiswa Akuntansi FE UST

\section{Pengaruh Ekspektasi Pendapatan Terhadap Minat Berwirausaha Mahasiswa Akuntansi FE UST}

Ekspektasi Pendapatan adalah harapan seseorang untuk menerima timbal balik berupa materi yang dihasilkan dari usahanya (Pamungkas, 2017). Dalam memilih pekerjaan salah satu faktor penting yang harus dipertimbangkan adalah gaji atau pendapatan. Dengan pendapatan tersebut, seseorang dapat memenuhi kebutuhan sehari-hari baik primer, sekunder dan tersier. Setiap individu memiliki kebutuhannya masing-masing, semakin banyak kebutuhan yang harus dicukupi, maka semakin besar pula pendapatan yang harus didapatkan tentunya dengan hasil usahanya.

Ekspektasi pendapatan dapat dikaitkan dengan Theory of Planned Behavior (TPB). Seseorang yang memiliki keinginan untuk memperoleh pendapatan yang tinggi cenderung akan mencari cara untuk mencapai tujuan tersebut, salah satunya dengan cara menjadi seorang 
wirausaha. Seseorang dengan harapan pendapatan yang lebih tinggi daripada bekerja menjadi karyawan menjadi daya tarik untuk menjadi wirausaha. Oleh karena itu, seseorang akan menentukan perilaku yang akan dipilihnya berdasarkan ekspektasinya tersebut.

Ekspektasi pendapatan juga dapat dikaitkan dengan teori atribusi, ekspektasi pendapatan merupakan faktor internal dari diri seseorang. Seseorang yang telah memiliki ekspektasi pendapatan yang tinggi dan memilih menjadi wirausaha akan berusaha mencapai tujuan tersebut. Oleh karena itu, ekspektasi pendapatan dapat dikaitkan dengan teori atribusi. Berdasarkan penjelasan dan analisis pengembangan hipotesis diatas, maka hipotesis dalam penelitian ini adalah:

H4: Ekspektasi Pendapatan Berpengaruh Positif Terhadap Minat Berwirausaha Mahasiswa Akuntansi FE UST

\section{METODOLOGI PENELITIAN}

\section{Jenis dan Sumber Data Penelitian}

Jenis data yang digunakan dalam penelitian ini adalah kuantitatif. Sumber data dalam penelitian ini adalah data primer. Instrumen penelitian ini mengunakan uji kualitas data berupa pengujian validitas dan reliablilitas kepada mahasiswa prodi akuntansi FE UST angkatan 2016-2018. Pengambilan sampel mengunakan snowball sampling. Jumlah populasi 505 mahasiswa dengan menggunakan sampel 85 mahasiswa. Teknik pengampilan sampel penelitian ini menggunakan purposive sampling.

\section{Metode Analisis dan Hipotesis Penelitian}

Metode analisis data penelitian ini dengan statistic deskriptif, kemudian pengujiam asumsi klasik dengan uji normalitas, uji linearitas, uji multikolinearitas, dan uji heterokedastitas. Penjelasan masing-masing pengujian asumsi klasik akan diuraikan seperti di bawah ini. Lanjutan pengujian untuk metode analisis yang digunakan untuk menguji pengaruh variabel bebas terhadap variabel terikat dengan Regresi Linear Berganda, Uji F, Uji t dan Uji Determinasi.

\section{Operasional Variabel Penelitian}

Penelitian ini menggunakan 1 (satu) variabel bebas dan 4 (empat) variabel terikat. Variabel bebas pada penelitian ini adalah minat berwirausaha $(Y)$. variabel terikat dalam penelitian ini adalah pendidikan kewirausahaan (X1), motivasi berwirausaha (X2), lingkungan keluarga (X3), dan ekspektasi pendapatan (X4).

\section{Minat Berwirausaha}

Pengukuran variabel Minat Berwirausaha dilakukan menggunakan skala Likert yang menggunakan scoring, yaitu dengan menyediakan jawaban 1-4 pada setiap pertanyaan, antara lain Sangat Setuju (SS), Setuju (S), Tidak Setuju (TS), dan Sangat Tidak Setuju (STS).

\section{Pendidikan Kewirausahaan}

Saat ini pendidikan telah menjadi kebutuhan dan tanggung jawab manusia sebagai individu dan anggota masyarakat. Agar setiap individu dapat mewujudkan kehidupan yang sejahtera dan mandiri, maka mereka, baik yang memberi maupun yang mencari pendidikan hendaknya memiliki pandangan hidup serta pemahaman tentang kewirausahaan (Hantoro, 2005: 19). Pengukuran variabel Pendidikan Kewirausahaan dilakukan menggunakan skala Likert yang menggunakan scoring, yaitu dengan menyediakan jawaban 1-4 pada setiap 
pertanyaan, antara lain Sangat Setuju (SS), Setuju (S), Tidak Setuju (TS), dan Sangat Tidak Setuju (STS).

\section{Motivasi Berwirausaha}

Motivasi berwirausaha tidak ada sejak seseorang lahir di dunia namun motivasi berwirausaha dapat dilatih dan dikembangkan. Menurut Sari (2017) motivasi memiliki peran dalam memeberikan kekuatan mental seseorang. Jika kebutuhan pertama sudah terpenuhi maka akan muncul kebutuhan kedua, ketiga dan seterusnya meskipun tingkat kebutuhan tersebut seluruhnya tidak harus terpenuhi. Kebutuhan akan terus muncul pada tingkat yang lebih tinggi, walaupun kebutuhan yang tingkat rendah belum terpenuhi secara maksimal. Pengukuran variabel Motivasi Berwirausaha dilakukan menggunakan skala Likert yang menggunakan scoring, yaitu dengan menyediakan jawaban 1-4 pada setiap pertanyaan, antara lain Sangat Setuju (SS), Setuju (S), Tidak Setuju (TS), dan Sangat Tidak Setuju (STS).

4. Lingkungan Keluarga

Lingkungan Keluarga adalah kelompok masyarakat terkecil yang terdiri dari ayah, ibu, anak dan anggota keluarga yang lain. Jika suatu keluarga memberikan pengaruh positif terhadap minat berwirausaha, maka minat berwirausaha akan terbentuk karena di dalam keluarga saling mempengaruhi baik langsung amupun tidak langsung. Orang tua yang berwirausaha dalam bidang tertentu dapat menimbulkan minat anaknya untuk berwirausaha menurut Ahmad Syafii dalam (Putra, Darma, 2018). Pengukuran variabel Lingkungan Keluarga dilakukan menggunakan skala Likert yang menggunakan scoring, yaitu dengan menyediakan jawaban 1-4 pada setiap pertanyaan, antara lain Sangat Setuju (SS), Setuju (S), Tidak Setuju (TS), dan Sangat Tidak Setuju (STS).

\section{Ekspektasi Penapatan}

Menurut Adhitama (2014) Ekspektasi pendapatan yang tinggi dan tidak terbatas maka dapat meningkatkan minat berwirausaha pada mahasiswa. merupakan harapan untuk memperoleh penghasilan lebih tinggi sehingga dengan ekspektasi pendapatan yang lebih tinggi maka akan semakin meningkatkan minat berwirausaha pada mahasiswa. Pengukuran variabel Ekspektasi Pendapatan dilakukan menggunakan skala Likert yang menggunakan scoring, yaitu dengan menyediakan jawaban 1-4 pada setiap pertanyaan, antara lain Sangat Setuju (SS), Setuju (S), Tidak Setuju (TS), dan Sangat Tidak Setuju (STS).

\section{HASIL DAN PEMBAHASAN \\ Hasil Penelitian}

\section{Statistik Deskriptif}

Tabel 1. Uji Statistik Deskriptif

\begin{tabular}{lccccc}
\hline & N & Min & Max & Mean & $\begin{array}{c}\text { Std. } \\
\text { Deviaton }\end{array}$ \\
\hline Pendidikan Kewirausahaan & 85 & 15 & 28 & 23.54 & 2.684 \\
Motivasi Berwirausaha & 85 & 45 & 71 & 58.47 & 5.607 \\
Lingkungan Keluarga & 85 & 12 & 24 & 18.99 & 2.942 \\
Ekspektasi Pendapatan & 85 & 8 & 16 & 13.24 & 2.057 \\
Minat Berwirausaha & 85 & 17 & 28 & 22.52 & 3.221 \\
\hline
\end{tabular}

Sumber Data: Data Primer, Diolah dengan SPSS V.20, (2020) 
Dapat diketahui bahwa analisis berupa tanggapan responden penelitian pada masingmasing instrumen pernyataan dalam kuesioner. Butir-butir instrumen diukur menggunakan skala likert dengan skala satu sampai dengan empat. Variabel independen, pendidikan kewirausahaan menghasilkan nilai minimal sebesar 15 , nilai maksimal 28 , nilai rata-rata 23,54 dan standar deviasi 2,684. Motivasi berwirausaha menghasilkan nilai minimal 45 , nilai maksimal 71 , rata-rata 58,47 , dan standard deviation 5,604. Lingkungan keluarga menghasilkan nilai minimal 12 , nilai maksimal 24, rata-rata 18,99, dan standard deviation 2,942. Ekspektasi pendapatan menghasilkan nilai minimal 8 , nilai maksimal 16, rata-rata 13,24, dan standard deviation 2,057. Variabel dependen minat berwirausaha menghasilkan nilai minimal 17 , nilai maksimal 28 , ratarata 22,52, dan standard deviation 3,221.

\section{Uji Asumsi Klasik}

Uji Normalitas

Tabel 2. Hasil Uji Normalitas

\begin{tabular}{llr}
\hline & & Unstandardized Residual \\
\hline $\mathrm{N}$ & & 85 \\
Normal Parameters, & Mean & $0 \mathrm{E}-7$ \\
& Std. Deviation & 2.03700205 \\
Most Extreme & Absolute & .058 \\
Differences & Positive & .058 \\
& Negative & -.041 \\
Kolmogorov-Smirnov Z & & .530 \\
Asymp. Sig. (2-tailed) & & .941 \\
\hline
\end{tabular}

Sumber Data: Data Primer, Diolah dengan SPSS V.20, (2020)

Dapat diketahui bahwa nilai uji Kolmogorov smirnov sebesar 0,530 dan nilai signifikansi sebesar 0,941. nilai signifikansi Asymp sig.(2-tailed) dengan lebih besar dari batasan nilai normalitas sebesar 0,05 , sehingga variabel dalam penelitian ini berdistribusi normal.

\section{Uji Hipotesis}

\section{Analisis Regresi Linear Berganda}

Tabel 3. Tabel Hasil Analisis Regresi Linear Berganda

\begin{tabular}{|c|c|c|c|c|c|c|}
\hline \multirow[b]{2}{*}{ Model } & & \multicolumn{2}{|c|}{$\begin{array}{l}\text { Unstandardized } \\
\text { Coefficients }\end{array}$} & \multirow{2}{*}{$\begin{array}{l}\text { Standardized } \\
\text { Coefficients } \\
\text { Beta }\end{array}$} & \multirow[b]{2}{*}{$t$} & \multirow[b]{2}{*}{ Sig. } \\
\hline & & B & Std. Error & & & \\
\hline \multirow[t]{7}{*}{1} & (Constant) & .067 & 2.484 & & .027 & .979 \\
\hline & Pendidikan & & & & & \\
\hline & $\begin{array}{l}\text { Kewirausahaa } \\
n(X)\end{array}$ & -.023 & .117 & -.019 & -.195 & .846 \\
\hline & Motivasi & & & & & \\
\hline & $\begin{array}{l}\text { Berwirausaha } \\
\text { (X2) }\end{array}$ & .134 & .058 & .233 & 2.322 & .023 \\
\hline & $\begin{array}{l}\text { Lingkungan } \\
\text { Keluarga (X3) }\end{array}$ & .244 & .096 & .223 & 2.549 & .013 \\
\hline & Ekspektasi & .795 & .128 & .508 & 6.192 & .000 \\
\hline
\end{tabular}


Pendapatan

(X4)

Sumber Data: Data Primer, Diolah dengan SPSS V.20, (2020)

Berdasarkan tabel 3 di atas yang diolah menggunakan program SPSS versi 20, analisis regresi linear berganda diperoleh persamaan regresi sebagai berikut:

\section{$Y=0,067-0,023 X 1+0,134 X 2+0,244 X 3+0,795 X 4+e$}

Persamaan regresi tersebut menunjukkan bahwa tiga variabel koefisien regresi berganda memiliki pengaruh positif. Berikut interpretasi besarnya nilai dari masing-masing koefisiennya berdasarkan persamaan regresi di atas:

1) Nilai konstan sebesar 0,067 menunjukkan bahwa, apabila pendidikan kewirausahaan, motivasi berwirausaha, lingkungan keluarga, dan ekspektasi pendapatan nilainya adalah 0, maka minat berwirausaha nilainya adalah 0,067.

2) Koefisien regresi variabel pendidikan kewirausahaan sebesar $-0,023$. Maka $\mathrm{H} 1$ ditolak yang artinya pendidikan kewirausahaan berpengaruh negatif terhadap minat berwirausaha mahasiswa Prodi Akuntansi FE UST.

3) Koefisien regresi variabel motivasi berwirausaha sebesar 0,134 , artinya jika variabel pendidikan kewirausahaan, lingkungan keluarga, dan ekspektasi pendapatan nilainya tetap dan motivasi berwirausaha mengalami kenaikan sebesar $1 \%$, maka minat berwirausaha akan mengalami peningkatan sebesar 0,134 . Koefisien bernilai positif artinya terjadi hubungan positif antara motivasi berwirausaha dengan minat berwirausaha. Maka H2 diterima yang artinya motivasi berwirausaha berpengaruh positif terhadap minat berwirausaha mahasiswa Prodi Akuntansi FE UST.

4) Koefisien regresi variabel lingkungan keluarga sebesar 0,244 , artinya jika variabel pendidikan kewirausahaan, motivasi berwirausaha, dan ekspektasi pendapatan nilainya tetap dan lingkungan keluarga mengalami kenaikan sebesar 1\%, maka minat berwirausaha akan mengalami peningkatan sebesar 0,244 . Koefisien bernilai positif artinya terjadi hubungan positif antara lingkungan keluarga dengan minat berwirausaha. Maka $\mathrm{H} 3$ diterima yang artinya lingkungan keluarga berpengaruh positif terhadap minat berwirausaha mahasiswa Prodi Akuntansi FE UST.

5) Koefisien regresi variabel ekspektasi pendapatan sebesar 0,795 , artinya jika variabel pendidikan kewirausahaan, motivasi berwirausaha, dan lingkungan keluarga nilainya tetap dan lingkungan keluarga mengalami kenaikan sebesar $1 \%$, maka minat berwirausaha akan mengalami peningkatan sebesar 0,795. Koefisien bernilai positif artinya terjadi hubungan positif antara ekspektasi pendapatan dengan minat berwirausaha. Maka H4 diterima yang artinya ekspektasi pendapatan berpengaruh positif terhadap minat berwirausaha mahasiswa Prodi Akuntansi FE UST.

\section{Uji Simultan (Uji F)}

Tabel 4. Hasil Uji Simultan (Uji F)

ANOVA $^{b}$

\begin{tabular}{lllllll}
\hline Model & Sum of Squares & Df & Mean Square & F & Sig. \\
\hline 1 & Regression & 522.676 & 4 & 130.669 & 29.992 &, $000^{\mathrm{b}}$ \\
& Residual & 348.548 & 80 & 4.357 & & \\
& Total & 871.224 & 84 & & & \\
\hline
\end{tabular}

Sumber Data: Data Primer, Diolah dengan SPSS V.20, (2020) 
Dapat diketahui bahwa nilai $F$ sebesar 29.992 dan nilai signifikansinya $0,000<0,05$. Hal ini menunjukkan terdapat pengaruh signifikan pada variabel pendidikan kewirausahaan, motivasi berwirausaha, lingkungan keluarga, dan ekspektasi pendapatan terhadap minat berwirausaha secara simultan atau bersama-sama, sehingga model regresi yang digunakan dalam penelitian ini layak digunakan data penelitian.

\section{Uji Parsial (Uji t)}

Tabel 5. Hasil Uji Parsial (Uji t)

\section{Coefficients $^{\mathrm{a}}$}

\begin{tabular}{|c|c|c|c|c|c|c|}
\hline \multirow[b]{2}{*}{ Model } & & \multicolumn{2}{|c|}{$\begin{array}{l}\text { Unstandardized } \\
\text { Coefficients }\end{array}$} & \multirow{2}{*}{$\begin{array}{l}\text { Standardized } \\
\text { Coefficients } \\
\text { Beta } \\
\end{array}$} & \multirow[b]{2}{*}{$t$} & \multirow[b]{2}{*}{ Sig. } \\
\hline & & $\mathrm{B}$ & Std. Error & & & \\
\hline \multirow[t]{8}{*}{1} & (Constant) & .067 & 2.484 & & .027 & .979 \\
\hline & Pendidikan & & & & & \\
\hline & $\begin{array}{l}\text { Kewirausahaa } \\
n(X)\end{array}$ & -.023 & .117 & -.019 & -.195 & .846 \\
\hline & Motivasi & & & & & \\
\hline & $\begin{array}{l}\text { Berwirausaha } \\
\text { (X2) }\end{array}$ & .134 & .058 & .233 & 2.322 & .023 \\
\hline & Lingkungan & & & & & \\
\hline & $\begin{array}{l}\text { Keluarga (X3) } \\
\text { Ekspektasi }\end{array}$ & .244 & .096 & .223 & 2.549 & .013 \\
\hline & $\begin{array}{l}\text { Pendapatan } \\
\text { (X4) }\end{array}$ & .795 & .128 & .508 & 6.192 & .000 \\
\hline
\end{tabular}

Dapat diketahui bahwa untuk menguji hipotesis $(\mathrm{H} 1)$, diperoleh nilai t hitung variabel pendidikan kewirausahaan sebesar -0,195 < 1,99006 dengan signifikansi sebesar 0,846 > 0,05 , maka dapat disimpulkan bahwa pendidikan kewirausahaan memiliki pengaruh negatif terhadap minat berwirausaha. Oleh karena itu, $\mathrm{H} 1$ menyatakan bahwa pengaruh pendidikan kewirausahaan terhadap minat berwirausaha mahasiswa akuntansi FE UST tidak terdukung.

Pengujian hipotesis kedua $(\mathrm{H} 2)$, diperoleh nilai $t$ hitung variabel motivasi berwirausaha sebesar 2,322 > 1,99006 dengan signifikansi sebesar 0,023 $<0,05$, maka dapat disimpulkan bahwa motivasi berwirausaha memiliki pengaruh positif terhadap minat berwirausaha mahasiswa akuntansi. Oleh karena itu, $\mathrm{H} 2$ menyatakan bahwa pengaruh motivasi berwirausaha terhadap minat berwirausaha mahasiswa akuntansi FE UST terdukung.

Pengujian hipotesis ketiga $(\mathrm{H} 3)$, diperoleh nilai t hitung variabel lingkungan keluarga sebesar 2,549 >1,99006 dengan signifikansi sebesar 0,013<0,05, maka dapat disimpulkan bahwa lingkungan keluarga memiliki pengaruh positif terhadap minat berwirausaha mahasiswa akuntansi. Oleh karena itu, H3 menyatakan bahwa pengaruh lingkungan keluarga terhadap minat berwirausaha mahasiswa akuntansi FE UST terdukung.

Pengujian hipotesis keempat $(\mathrm{H} 4)$, diperoleh nilai $t$ hitung variabel ekspektasi pendapatan sebesar 6,192 >1,99006 dengan signifikansi sebesar 0,000 00,05, maka dapat disimpulkan bahwa ekspektasi pendapatan memiliki pengaruh positif terhadap minat berwirausaha mahasiswa akuntansi. Oleh karena itu, H4 menyatakan bahwa pengaruh 
ekspektasi pendapatan terhadap minat berwirausaha mahasiswa akuntansi FE UST terdukung.

\section{Uji Determinasi $\left(\mathbf{R}^{2}\right)$}

\section{Tabel 6. Hasil Uji Determinasi $\left(\mathbf{R}^{2}\right)$}

\begin{tabular}{ccccc}
\hline Model & $\mathrm{R}$ & $\mathrm{R}$ Square & $\begin{array}{c}\text { Adjusted } \mathrm{R} \\
\text { Square }\end{array}$ & $\begin{array}{c}\text { Std. Error of the } \\
\text { Estimate }\end{array}$ \\
\hline 1 &, $775^{\mathrm{a}}$ &, 600 &, 580 & 2.087 \\
\hline
\end{tabular}

Sumber Data: Data Primer, Diolah dengan SPSS V.20, (2020)

Dapat diketahui bahwa nilai koefisien determinasi pada penelitian ini sebesar 0,580 . Hal ini menunjukkan bahwa pengaruh atau konstribusi independen yaiti pendidikan kewirausahaan, motivasi berwirausaha, lingkungan keluarga, dan ekspektasi pendapatan sebesar $58 \%$ mempengaruhi variabel dependen yaitu minat berwirausaha, sedangkan sisanya sebesar $42 \%(100 \%-58 \%)$ dipengaruhi oleh faktor lain di luar variabel yang telah digunakan.

\section{REKOMENDASI KEBIJAKAN}

\section{Rekomendasi}

Berdasarkan hasil pengujian data yang diproses SPSS V.20 sesuai dengan tujuan penelitian ini, maka rekomendasi hasil penelitian ini antara lain:

1) Pendidikan kewirausahaan berpengaruh negatif terhadap minat berwirausaha mahasiswa prodi akuntansi FE UST.

2) Motivasi berwirausaha berpengaruh positif terhadap minat berwirausaha mahasiswa prodi akuntansi FE UST.

3) Lingkungan keluarga berpengaruh positif terhadap minat berwirausaha mahasiswa prodi akuntansi FE UST.

4) Ekspektasi pendapatan berpengaruh positif terhadap minat berwirausaha mahasiswa prodi akuntansi FE UST.

\section{Kebijakan}

Bedasarkan hasil dan interpretasi penelitian ini, maka peneliti memberikan saran sebagai rekomendasi kebijakan antara lain:

1) Penelitian ini belum menggunakan model penelitian moderasi atau intervening, oleh karena itu peneliti selanjutnya diharapkan dapat menggunakan salah satu model penelitian tersebut.

2) Penelitian ini hanya menggunakan satu sumber data penelitian yaitu kuesioner melalui google form, oleh karena itu peneliti selanjutnya diharapkan dapat menambah sumber data dengan teknik penelitian seperti wawancara.

3) Penelitian ini hanya fokus pada mahasiswa aktif angkatan 2017, 2018 dan alumni angkatan 2016 Prodi Akuntansi FE UST, oleh karena itu peneliti selanjutnya dapat memperluas sampel penelitian, tidak hanya satu prodi akan tetapi semua prodi di UST maupun lingkup yang lebih luas dari berbagai universitas serta dapat membandingkan minat berwirausaha antara Perguruan Tinggi Negeri maupun Perguruan Tinggi Swasta. 


\section{DAFTAR PUSTAKA}

Adhitama, P. P. (2014). Faktor-Faktor Yang Mempengaruhi Minat Berwirausaha (Studi Kasus Mahasiswa Fakultas Ekonomika Dan Bisnis Undip, Semarang).

Ajzen, I. (1991). Theory of Planned Behavior. University of Massachusetts at Amherst, Academic press.inc.

Hantoro, S. (2005). Kiat Sukses Berwirausaha. ADICITA KARYA NUSA.

Heider, F. (1958). The Psychology of Interpersonal Relations. Wiley.

Inayati, F. E. (2018). Pengaruh Pendidikan Kewirausahaan, Sikap, Lingkungan Keluarga, dan Motivasi terhadap Minat Berwirausaha.

Noviantoro, G. (2017). Pengaruh Pengetahuan Kewirauasahaan, Motivasi Berwirausaha Dan Lingkungan Keluarga Terhadap Minat Bwerwirausaha Pada Mahasiswa Akuntansi Fakultas Ekonomi Universitas Negeri Yogyakarta. 01, 1-7. http://www.albayan.ae

Pamungkas, P. A. (2017). Pengaruh Self Efficacy, Pendidikan Kewirausahaan Dan Ekspektasi Pendapatan Terhadap Minat Berwirausaha Mahasiswa Program Studi Akuntansi Fakultas Ekonomi Universitas Negeri Yogyakarta.

Paramitasari, F. (2016). Pengaruh Motivasi Berwirausaha Dan Pengetahuan Kewirausahaan Terhadap Minat Berwirausaha Siswa Kelas Xi Kompetensi Keahlian Administrasi Perkantoran SMK N 1 Bantl.

Purnomo, H. (2020). Coba Lihat, Banyaknya Pengangguran Terdidik di Tahun 2020. https://www.kompasiana.com/heryizkak7272/5e27aff4d541df08eb003b42/coba-lihatfenomena-banyaknya-pengangguran-terdidik-di-tahun-2020?page=all\#: :text=Kenaikan tingkat pengangguran justru terjadi,tinggi semakin meningkat ditahun 2019.

Putra, Darma, I. (2018). Analisis Faktor-Faktor Yang Mempengaruhi Minat Berwirausaha Mahasiswa Fakultas Ekonomi Universitas Islam Indonesia. Skripsi.

Saiman, L. (2009). Kewirausahaan (Teori, Praktik dan Kasus-kasus). Salemba Empat.

Sari, P. P. (2017). Pengaruh Ekspektasi Pendapatan, Motivasi, Pendidikan Kewirausahaan, Dan Norma Subyektif Terhadap Minat Berwirausaha (Studi Kasus pada Mahasiswa S1 Fakultas Ekonomi Universitas Negeri Yogyakarta Angkatan 2013-2014). Universitas Nusantara PGRI Kediri, 01, 1-7. http://www.albayan.ae

Semiawan, C. (2010). Pendidikan Keluarga Dalam Era Global. PT. Preenhalindo.

Setiawan, D. (2016). Pengaruh Ekspektasi Pendapatan, Lingkungan Keluarga Dan Pendidikan Kewirausahaan Terhadap Minat Berwirausaha. June, 4-13.

Sintya, N. M. (2019). Pengaruh Motivasi, Efikasi Diri, Ekspektasi Pendapatan, Lingkungan Keluarga, Dan Pendidikan Kewirausahaan Terhadap Minat Berwirausaha Mahasiswa Jurusan Akuntansi Di Universitas Mahasaraswati Denpasar. Jurnal Sains, Akuntansi Dan Manajemen, 1(1), 337-380.

Sutrisno. (2003). Pengembangan pendidikan berwawasan kewirausahaan sejak usia dini.

Utami, M. A. P. (2017). Pengaruh Motivasi Internal Dan Motivasi Eksternal Terhadap Minat Berwirausaha Mahasiswa Jurusan Akuntansi Non Reguler. 6, 5-9. 